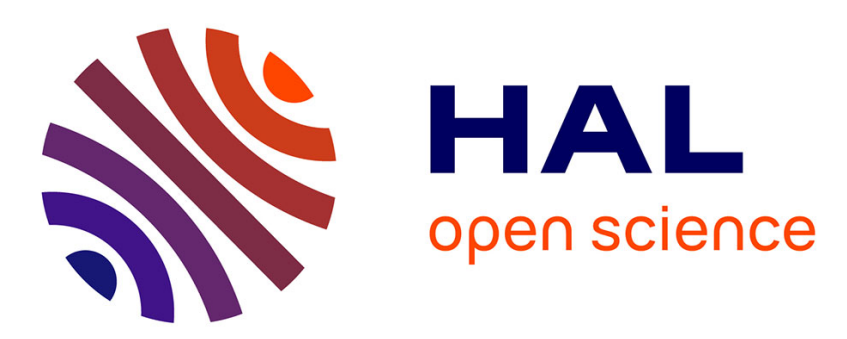

\title{
Farm typology to manage sustainable blackleg resistance in oilseed rape
}

Fargue-Lelièvre, Moraine, Coléno

\section{To cite this version:}

Fargue-Lelièvre, Moraine, Coléno. Farm typology to manage sustainable blackleg resistance in oilseed rape. Agronomy for Sustainable Development, 2011, 31 (4), pp.733-743. 10.1007/s13593-011-0044-y . hal-00930516

\section{HAL Id: hal-00930516 https://hal.science/hal-00930516}

Submitted on 1 Jan 2011

HAL is a multi-disciplinary open access archive for the deposit and dissemination of scientific research documents, whether they are published or not. The documents may come from teaching and research institutions in France or abroad, or from public or private research centers.
L'archive ouverte pluridisciplinaire HAL, est destinée au dépôt et à la diffusion de documents scientifiques de niveau recherche, publiés ou non, émanant des établissements d'enseignement et de recherche français ou étrangers, des laboratoires publics ou privés. 


\title{
Farm typology to manage sustainable blackleg resistance in oilseed rape
}

\author{
Agnès Fargue-Lelièvre • Marc Moraine • \\ François-Christophe Coléno
}

Accepted: 10 June 2011 / Published online: 12 August 2011

(C) INRA and Springer Science+Business Media B.V. 2011

\begin{abstract}
Blackleg-Leptosphaeria maculans - is a major worldwide pest for oilseed rape. Blackleg is an airborne pathogen spreading over several kilometres and surviving for at least 3-5 years on crop residues. In oilseed rape, the classical control strategy against blackleg is varietal resistance. However, genetic diversity is decreasing in agricultural crops. Moreover, at the farm level, management of oilseed resistance to blackleg must be adapted to take into account specific farm household objectives and organisation. Therefore, the different types of oilseed management should be identified. Here, we built a typology of oilseed rape management focusing on blackleg management. We used a methodology based on expert knowledge to analyse 32 farms of three French regions. Our results show that eight types of oilseed rape management were identified and can be discriminated according to the risk of blackleg resistance breakdown. We thus identified three categories, high, low, and medium risks. High risk management types have both a low level of oilseed rape management flexibility and a high level of inputs. Low risk systems are systems where oilseed rape is only a minor part of farmer sales and where inputs are minimised. Medium risk systems are systems where oilseed rape is integrated in the rotation, and where input use is optimised by taking into account the short rotation and the expected revenue. Our typology therefore allows to define practices not only on classical agronomic criteria but also on crop sales part in the farm and on input levels.
\end{abstract}

A. Fargue-Lelièvre $(\bowtie) \cdot$ M. Moraine $\cdot$ F.-C. Coléno

UMR SAD-APT, INRA-AgroParisTech,

16 rue Claude Bernard,

75231 Paris Cedex 05, France

e-mail: agnes.lelievre@agroparistech.fr
Keywords Sustainability B Blackleg · Varietal resistance . Technical change - Farm typology Brassica napus . Leptosphaeria maculans

\section{Introduction}

Blackleg (Leptosphaeria maculans) is one of the major diseases in oilseed rape worldwide (Fitt et al. 2006; West et al. 2001). It can result in major yield losses $(50 \%$ yield losses have been observed in Australia and $5-20 \%$ in France) and is the main disease of oilseed rape in the UK (Fitt et al. 2006).

This pathogen is airborne and can spread over several kilometres but the greatest risk is within $500 \mathrm{~m}$ of the inoculum source (Khangura and Barbetti 2001). The pathogen can survive for at least 3-5 years on crop residues (Marcroft et al. 2004; Naseri 2006). Agricultural practices can spread it via soil and spore transport on tools but they can also limit pathogen dispersion.

In general, pathogen control during crop production is mainly a lengthening of the period between two oilseed rape crops and the destruction and ploughing in of crop residues. Neither of these techniques may be very popular in view of the increase in oilseed rape area and conservation agriculture since it would curtail oilseed rape area development in order to lengthen return time and because ploughing uses more time and fuel than minimum tillage for the same area. Chemical means of control are helpful but are no cure-all, as their duration of protection is less than the contamination period (Aubertot et al. 2004). In oilseed rape, the most commonly used defence against blackleg is varietal resistance. Varietal selection aims for genetic resistance to this pathogen, mainly through specific (monogenic, qualitative, or major gene) resistance 
(Aubertot et al. 2006), which may cause high selective pressure on the pathogen and an adaptive response, as happened in France and in Australia (Rouxel et al. 2003; Sprague et al. 2006). Possible explanation of resistance breakdown in France (Rouxel et al. 2003) is the rapid increase in oilseed rape acreage, associated with changes in cultural practices (closer crop rotations and minimum tillage) and the proportion of cultivars with the same specific resistance. The solution is the combination of polygenic and specific monogenic resistance to maintain an acceptable yield (Aubertot et al. 2004; Sivasithamparam et al. 2005) associated with suitable agricultural practices to preserve their sustainability, defined as the preservation of the resistance of the population to the pathogen (West et al. 2001; Mestries 2005). One solution at the field scale would be to change cultivars regularly to switch the specific monogenic resistance present in the crop and thus escape the disease from the majority of spores released from the previous season's crop debris as most of these will be avirulent on the new cultivar. This will thus reduce the proportion of virulent pathogens in the pathogen population (Sprague et al. 2006). But with genetic diversity erosion in agricultural crops, plant resistance must be maintained through sustainable management of these resistances.

Means of sustainable management of plant resistance using cropping techniques can be defined on three scales: the field, the farm, and the small region (Aubertot et al. 2006; Schneider et al. 2006) which means that blackleg pressure must be managed on a wider scale than the fieldat least at the farm level-since the pathogen can be dispersed over a region. However, the regional level is not well documented and will not be studied here.

Our hypothesis is that current crop management does not allow sustainability of varietal resistance but that scope for change exists. As stated by Coléno et al. (2005), it is necessary to know farm household objectives for managing the system in a particular way in order to enhance its capacity to adopt new technologies or organisation. Whereas model-based farming system analysis could potentially prove very useful, this is not yet the case, mainly because the models do not include enough processes relevant to the analysis of on-farm decision making (McCown 2002).

The objective of this study is thus to identify different types of oilseed rape management at the farm level and their associated risk of blackleg resistance breakdown. We aim at helping advisors to classify farms according to this risk of resistance breakdown and to their flexibility in order for them to suggest less risky cropping techniques to existing systems where possible and to identify risky systems that cannot easily be changed. We thus chose to produce a typology of farming systems for an easy use by the advisors.
Several methods are available to study oilseed rape management systems. Maton et al. (2005) discriminates two kinds of farm typology: those using "positivist" methods where types are constructed from first principles and using statistical data (Köbrich et al. 2003; Maton et al. 2005) and those using "constructivist" methods where types are based on expert knowledge (Landais 1998; Girard et al. 2001).

In this study, we did not have any prior hypotheses about the perception and management of blackleg management in the farms. We also needed expert knowledge we did not then possess. We thus decided to use a constructivist approach like that used by Girard et al. (2008), which uses knowledge coming both from expert and surveys. This construction of the typology is based on the prototypical theory (Rosch 1978) where types are defined by their centre as poles characterised by the most typical practices and their rationale. Proximity of farms to each type is then measured as degrees of similarity. This method was developed to study livestock farming systems but has never been tested on crop farming systems. In both cases, the method aims at representing the diversity of management strategies related to a specific problem.

Other farm typologies have been made, whether to analyse agricultural trajectories (Iraizoz et al. 2007) or to analyse the effect of policies on farming systems (Köbrich et al. 2003). In both cases, even though the types were finally or partially determined using a cluster analysis as in Girard et al. (2008), the farms were initially chosen according to hypotheses about the determining factors: quantitative and qualitative data were collected about the factors to use in the segmentation and typing. In our case, we wanted to identify the determining factors that differentiated the farm management systems in relation to sustainability of blackleg resistance without knowledge of farmers' practices.

For this study, we thus decided to use the same method to build our farm typology as Girard et al. (2008) for stock farming in the South of France, which we adapted to the study of crop farming. This method is not based on quantitative technical and economic data but on qualitative data concerning farming practices and its exploitation with experts. It can be broken down into four phases: (1) precisely identifying the study outlines (question, area studied, sample and sampling criteria, and experts who will participate in the study); (2) conducting semistructured interviews with farmers using interview guidelines and summarising these interviews; (3) formalising the data with the help of experts to identify diversity criteria; and (4) using these criteria to identify types. Girard et al. (2001) used repertory grids (Bradshaw et al. 1993) to analyse their data via a multiple correspondence analysis, a repertory grid being a rectangular matrix with the ratings in columns and the constructs in lines. 
In this study, we applied this method to crop farming, adapting it when necessary in order to identify cropping system management within the farm, focusing on oilseed rape management and its effect on the sustainability of resistance to blackleg. In particular, we compared oilseed rape cropping techniques on the farm with those identified by technical advisors and researchers as limiting resistance breakdown and we tried to understand how oilseed rape management decisions are taken at the farm level. One of the objectives of this typology of farming systems was to help the French oilseed technical advisory centre (Technical Centre for Oilseed Crops, CETIOM) adapt its advice to farm type.

\section{Materials and methods}

\subsection{Method used}

In the first phase, we used expert consultation and bibliographic reviews to identify existing French oilseed rape management systems and agronomic advice about blackleg in order to target the regions we would be studying and the data we would need to collect to define blackleg risk on farms. This led us to two regions, Centre and Vendée, and to the construction of interview guidelines for our farm survey. In the second phase of our study, we surveyed 32 farms using semi-structured interviews (Miles and Huberman 1994). We used our interview guidelines to gather data on the farm and its management such as production resources (cropped area, equipment, labour), production strategies (crop rotation and location, yield objectives, source of seeds, and harvest outlets), technical choices (cropping techniques, varietal choice, varietal changes, and crop succession) and disease management (including blackleg history, management techniques, and reaction to potential field contamination) as well as the possibility of adopting some of the recommended oilseed rape management techniques and their consequences on the organisation on the farm. We called this possibility of adopting new techniques flexibility within a type adapting to our case the definition of Dedieu and Ingrand (2010) of flexibility as an aptitude to adapt to circumstances and absorb changes. Flexibility was assessed by asking the farmer if he/she would be able to adopt such techniques, taking into account the major constraints they had described earlier. We let the farmers talk about their farms and crops, especially oilseed rape and blackleg, redirecting the questions only when necessary to fill the gaps in our interview guidelines. The opinions of the farmer were also noted during the course of the interview.

In the third phase, data from the farms were synthesised as practice cards each representing two or three qualitative and/or quantitative features of a farmer's practices that seemed to be relevant to resistance sustainability. These practice cards were defined by the problem studied. We brought together several scientific experts to define which attributes (combinations of techniques or of structural data) were relevant to resistance sustainability, using several practice cards of different farms and of different combinations of practices, and giving them additional information about the content of the interviews. The instructions to the experts were to segregate (1) farms considering their structural data and (2) practices considering combinations of techniques. Relevant attributes were practice combinations that could explain differences in risk levels between farms. For each attribute (or diversity criterion), the experts identified two extremely divergent practices (associated with qualitative values 1 and 5) and intermediate practices (associated with qualitative values 2, 3, and 4). Each farm was then positioned on this scale. Ten diversity criteria were identified by the expert panel as relevant to blackleg resistance sustainability on the farm: (1) adaptation of cropping techniques for maximum yield, (2) adaptation of cultivar choice to investment and resources, (3) choice of cultivars to optimise the field pattern use, (4) diversification of cultivars in space and time, (5) use of the field pattern to reduce the frequency of oilseed rape in the rotation, (6) adaptation of cropping techniques to limit damage to oilseed rape crop, (7) adaptation of oilseed rape management for maximum economic return (including inputs costs), (8) adaptation of management to limit the use of environmentally unfriendly products, (9) use of innovative techniques to optimise oilseed rape results and crop sustainability, and (10) the retrieval and use of information for planning cropping systems. These criteria account for oilseed rape management at the different levels of farmer's decision-making from the strategic considerations that will have a long-term effect to technical choices during the year.

For each farm, the value of each diversity criterion was then identified. As in Girard et al. (2008), there was thus a collective analysis and explanation of the data. Each farm was then represented by a combination of qualitative descriptors which could be compared between farms and were used to classify the farms.

Like Girard et al. (2008), our farms were grouped using correspondence analysis (disjunctive treatment) followed by an agglomerative hierarchical clustering (AHC) with XLStat $^{\circledR}$. Eight types were differentiated at the $5 \%$ level of significance. For each group, a farm type could then be described, to which each farm could be more or less close, one farm belonging to one or several types according to the distance of the former to the latter's centre. As in Girard et al. (2008), there is some continuity between types. However for our study, each farm was defined as belonging to the farm type it most closely 
resembled. A later validation of the types found using a repertory grid tool was done by the scientific experts who had defined the diversity criterion but also by two other scientific experts, one of whom is also a technical advisor. Our expert panel thus consisted in total of a public technical advisor, three scientific agronomic experts, and a technical expert. The main differences with the method described in Girard et al. (2008) is that the first stage of choosing the sample studied and clarifying the expectations was entirely done internally and that we only did one iteration of group discussion with experts and multivariate analysis.

\subsection{Study area}

Two French regions were chosen (Centre and Vendée) with different blackleg pressure and production context to analyse different oilseed rape management strategies and their impact on resistance sustainability. We chose two contrasting areas to see if blackleg pressure affected resistance management by farmers. Within each area, a variety of farms was surveyed. In the Centre area, 22 farms were surveyed. In the Vendée area, only 10 farms were surveyed because of lower blackleg pressure and less variability in production context.

According to CETIOM, in 2008, high blackleg pressure was found in the Centre region, while a medium-low blackleg pressure was found in the Vendée region.

The two regions studied (Centre and Vendée) differ only slightly in their oilseed rape production practices (Table 1): in the Centre region, there is more ploughing before sowing, which should diminish the risk of blackleg presence on residues. However, farm-grown seed is more often used, which may allow infected seeds to be used. Fungicides are more often used in the Centre region (93\% of the fields are treated) since blackleg pressure is high in the Centre and low in Vendée. Overall, the climate, the higher proportion of oilseed rape area, and the higher proportion of farm-grown seed in the Centre region may explain the higher pressure of blackleg in this region. In the Centre region, rape is sown earlier but harvested later due to different climatic conditions, but soil and climatic conditions also differ and vary within the two regions studied as do crop proportions.

\subsection{Farm sample}

Our hypothesis was that oilseed rape management choices depend partly on different socio-economic characteristics. To sample the widest range of rape management strategies, we chose farms so as to maximise the range of usable agricultural farm area (UAA), proportion of oilseed on the farm and production context (farm-grown seed or not, cattle or not etc.). From the databases of two local rape seed sellers, 32 farmers were chosen and surveyed according to these criteria and to their willingness to take part.

The farm sample surveyed covers a wide range of UAA and oilseed rape proportion (UAA from 30 to 470 ha and oilseed rape area from $5 \%$ to $45 \%$ of the UAA with a mean of $17 \%$ of the UAA cropped with oilseed rape) but also of production systems cropping and, according to the technical advisors partners (?) represents the diversity in these areas.

\section{Results and discussion}

\subsection{Sample studied}

Our sample does not reflect the regional mean but its diversity. For example, farm mean UAA is 118 ha for Centre farms and 74.8 ha for Pays de Loire (Vendée) according to French statistical data for 2006, whereas in our sample, mean farm UAA is 179 ha for Centre and 124 ha for Vendée. Rape areas on the farm are also bigger since we only studied farms producing oilseed rape. French statistical data gives us an oilseed rape area of $13 \%$ of the UAA in
Table 1 Main differences in cropping techniques of oilseed rape between the two regions studied (data source: Agreste Enquêtes Pratiques Culturales 2006)

\begin{tabular}{|c|c|c|}
\hline Cropping techniques & Centre & Poitou-Charentes (Vendée) \\
\hline Preceding crop & $53 \%$ wheat, $36 \%$ barley & $74 \%$ wheat, $17 \%$ barley \\
\hline Soil preparation & $\begin{array}{l}55.4 \% \text { ploughing, } 44.2 \% \text { other } \\
\text { soil tillage }\end{array}$ & $49.5 \%$ ploughing, $50 \%$ other soil tillage \\
\hline Seed origin & $\begin{array}{l}65 \% \text { certified seeds, } 34 \% \text { farm } \\
\text { seeds }\end{array}$ & $76 \%$ certified seeds, $19 \%$ farm seeds \\
\hline Sowing date & $\begin{array}{l}75 \% \text { between } 16 \text { and } 31 / 08,22 \% \\
\text { between } 1 \text { and } 15 / 09\end{array}$ & $\begin{array}{l}63 \% \text { between } 16 \text { and } 31 / 08,34 \% \\
\text { between } 1-15 / 09\end{array}$ \\
\hline Harvesting date & $\begin{array}{l}6 \% \text { before } 1 / 07,82 \% \text { between } 1 \\
\text { and } 15 / 07,12 \% \text { between } 16 \\
\text { and } 31 / 07\end{array}$ & $\begin{array}{c}29 \% \text { before } 1 / 07,68 \% \text { between } 1 \text { and } \\
15 / 07,3 \% \text { between } 16 \text { and } 31 / 07\end{array}$ \\
\hline $\begin{array}{l}\text { Percentage of fields treated } \\
\text { with at least one fungicide }\end{array}$ & $93 \%$ & $79 \%$ \\
\hline
\end{tabular}


Centre and $2 \%$ in Pays de Loire (Vendée), whereas we find a rape area of $22 \%$ of the UAA in Centre and $12 \%$ in Vendée.

However, our data reflect the balance between the two regions. The same can be said for fungicide use on oilseed rape since French statistical data tell us that $93 \%$ of the Centre farms and $79 \%$ of the Pays de Loire (Vendée) farms used at least one fungicide on oilseed rape. In our sample, $77 \%$ of the Centre farms and $80 \%$ of the Vendée farms used at least on fungicide on oilseed rape but this is because we surveyed five organic farms in Centre $(23 \%$, which is much higher than the regional mean) and none in Vendée. However, if we look more closely at our data, we see that $80 \%$ of Vendée farms used one fungicide per year, whereas in the Centre region, only the five organic farms used no fungicide, while six of the other farms used one fungicide, six used two, and the remaining five used three or four. Fungicide use on oilseed rape is thus much higher in Centre which reflects the regional data and is almost certainly a response to higher fungal pressure in the Centre region.

\subsection{Farm types}

\subsubsection{Description of types}

Using a classification tree (Fig. 1), eight cropping system types were defined as groupings of farms similar at the 5\% probability level for the attributes defined by the experts. These types can described by expressing their strategy and risk level: (1) in type A, oilseed rape is fairly unimportant; its management is simplified and practices are uniform over the farm and rarely change, with ploughing, high nitrogen fertilisation, and programmed pesticide applications; (2) in type $\mathrm{B}$, rape is included in a secondary crop rotation (for example cereal/oilseed rape when the primary crops are vegetables), as so little time is available for this crop and management is simplified; (3) in type $C$, the farm is managed around several crops. Rape is a minor break-crop. Its area is low with a long return time and it is managed with low investment but has its place in the system; (4) in type $\mathrm{D}$, risk is managed at the field pattern level by lengthening return times and choosing many varieties, which are regularly changed. The limiting factor is available time; (5) in type $\mathrm{E}$ are found different systems in which rape is managed intensively, limiting the risks with a high use of inputs but with short return times due to the high percentage of oilseed rape area and only 1-2 "surefire" varieties. This type is not very flexible; (6) in type F, farmers grow mainly cereals over large areas on fertile soils. They use highly intensive practices with much technology. Rape return time is around 3 years and varietal choice is complex and based on tests made on the farm; selling practices maximise the return; (7) in type G, there is a diversity of production contexts but the farmer has to take into account soil and climatic and/or organisational constraints. Practices are generally intensive and not time consuming but investment is made according to the expected return; (8) in type $\mathrm{H}$, the objective is sustainability of the system, the crop rotation is long, and the oilseed rape area small; there are few chemical inputs. Productivity is low and oilseed rape has a low economic importance in the system. For each farm type, experts determined the risk level for sustainability of blackleg resistance breakdown in this system based on their oilseed rape management practices (Table 2).
Fig. 1 Dendrogram showing the eight farm types $(A-H)$ established at the 5\% significance level according to the values of each of the 10 criteria for each of the 32 farms surveyed

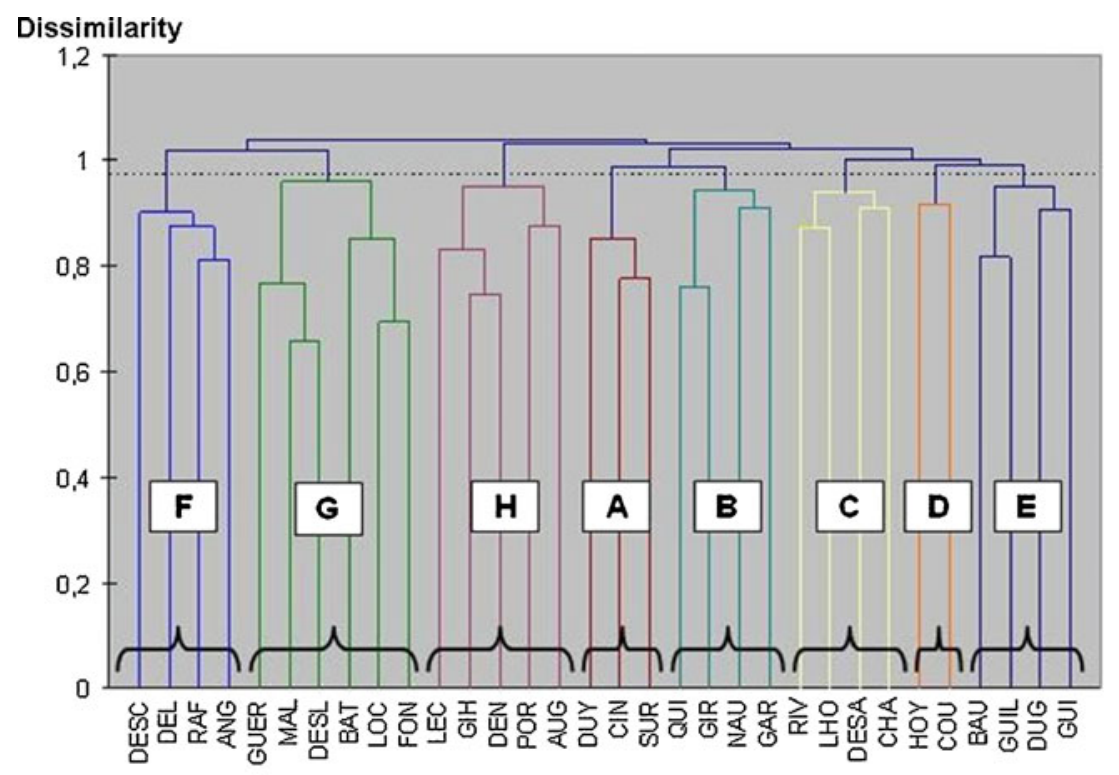

Farms 
Table 2 Structural data about the farm sample studied by farm type. In each line the range of variation found within the surveyed farms of the same type are given. UAA: usable agricultural farm area

\begin{tabular}{lllllll}
\hline $\begin{array}{l}\text { Number of farms } \\
\text { in each type }\end{array}$ & $\begin{array}{l}\text { Farm } \\
\text { type }\end{array}$ & $\begin{array}{l}\text { Risk } \\
\text { Level }\end{array}$ & $\begin{array}{l}\text { Farm } \\
\text { UAA (ha) }\end{array}$ & $\begin{array}{l}\text { Area cropped in } \\
\text { oilseed rape (\%) }\end{array}$ & $\begin{array}{l}\text { Plot batches } \\
\text { number }\end{array}$ & $\begin{array}{l}\text { Max distance to } \\
\text { farm (km) }\end{array}$ \\
\hline 3 & A & 5 & $30-162$ & $3-27$ & $3-4$ & $3-10$ \\
4 & B & 4 & $75-470$ & $6-27$ & $1-5$ & $1-17$ \\
4 & C & 1 & $87-313$ & $6-13$ & $1-2$ & $1-8$ \\
2 & D & 2 & $83-88$ & $20-23$ & 3 & $4-8$ \\
4 & E & 5 & $85-123$ & $6-33$ & $1-4$ & $2-3$ \\
4 & F & 4 & $200-400$ & $25-45$ & $2-18$ & $4-15$ \\
4 & G & 3 & $90-200$ & $17-34$ & $2-38$ & $3-20$ \\
5 & H & 2 & $90-200$ & $4-29$ & $1-42$ & $1-30$ \\
\hline
\end{tabular}

Table 2 shows that the whole sample studied is diverse for structural data like size, oilseed rape proportion, field dispersion within the farm, which may have an effect on oilseed rape importance for the farmer or on workload and thus may influence oilseed rape management.

Types $\mathrm{F}$ and $\mathrm{G}$ contain the biggest farms (together with type $\mathrm{H}$ ), have a high proportion of oilseed rape, and a dispersed field pattern. Types A, D, and E are small (101, 86 , and 102 ha mean UAA per farm respectively) whereas $\mathrm{B}$ and $\mathrm{F}$ have a mean UAA per farm of more than 200 ha (206 and 277 ha, respectively). In types B, C, and $\mathrm{H}$, oilseed rape is marginal (with $14 \%, 9 \%$, and $12 \%$ of the UAA, respectively) whereas oilseed rape is an important crop for types $\mathrm{F}$ and $\mathrm{G}$ ( $32 \%$ and $26 \%$, respectively). In these two types, oilseed rape returns to the same field in less than 4 years (sooner than advised) whereas it should be easier for farms of types B, C, and $\mathrm{H}$ to follow the advice to wait more than 4 years between two oilseed rapes. Types B, $\mathrm{C}$, and $\mathrm{E}$ have fields relatively close to the farm headquarters (mean maximum distance to farm of 5.6, 4.3, and $2.3 \mathrm{~km}$ ) whereas types $\mathrm{F}, \mathrm{G}$, and $\mathrm{H}$ are more dispersed (mean maximum distance to farm of 8.3, 10.5, and $9.4 \mathrm{~km}$ ). In types $\mathrm{F}, \mathrm{G}$, and $\mathrm{H}$, it may thus be harder to do several cropping operations on distant fields and some techniques like burying residues and ploughing the soil may not be feasible. As for field batch number, a farm type with a lot of batches will have a lot of isolated fields and may grow several cultivars and decrease selective pressure on blackleg at the farm scale.

Two types have the maximum risk level: types A and E. Type $\mathrm{E}$ is only found in a small area of each region where blackleg is not often found. However, type A is found only in Centre where blackleg is a real risk. The fact that farmers of this type do not change their management is explained by the place of oilseed rape in the farm income. It represents less than $10 \%$ of the UAA and the risk taken is balanced by releasing time for other crops.

Less risky types (D, C, and $\mathrm{H}$ ) are found both in areas where blackleg is often found or not, and thus do not seem to be influenced its presence.
Once these types were defined, it would have been interesting to validate them, especially as some types contain few farms (there are only two in type D). However, the sampling size and the features of this type could explain the small size of this group. To validate this typology would necessitate a survey of a large number of farms. Another way was to submit this typology to experts for individual validation of the types and their associated risk level as Cros et al. (2003) did for the SEPATOU model. In the literature, validation is usually not done as for crop models by comparing simulation results and observed results but by asking the opinion of the end users (Carberry et al. 2002), even though it remains problematic because of uncertainties (McCown 2002). In our case, we asked the advice of a technical advisor from our expert panel and of a researcher in resistance sustainability to validate our types and their risk level.

\subsubsection{Diversity between and within types}

A range of farms can be found in each type for their UAA and oilseed rape area (Table 3). Two exceptions: in type $\mathrm{F}$ can be found only farms of more than 200 ha, of which more than 30 ha are cropped with oilseed rape, which means more than $25 \%$ of the area cropped in oilseed rape and a short return time and a high risk level; farms in type $\mathrm{D}$ all have less than 100 ha with an oilseed rape area between 11 and 30 ha and thus $10-25 \%$ of oilseed rape on the farm and a return time of 4-10 years associated with a complex varietal choice, which explains the low risk level

Table 3 Farm types found during the survey according to their usable agricultural farm area $(U A A)$ and oilseed rape area in 2007

\begin{tabular}{llll}
\hline \multicolumn{4}{c}{ Rape cropping area } \\
\hline Farm UAA & $0-10$ ha & $11-30$ ha & $>30$ ha \\
$0-100$ ha & A B C H & DD E H G & - \\
$101-200$ ha & A E H & B E CC & A B E GGGG H \\
$>200$ ha & - & C H & B FFFF G \\
\hline
\end{tabular}


of this type. The other types do not present specific characteristics for UAA or oilseed rape proportion.

Table 4 shows the geographical distribution of farm types. Only a few types are found in the Vendée region whereas all types can be found in the Centre region-even the more risky types - even though blackleg is a greater risk in this region. Types A, B, C, D, and G are found only in parts of the Centre where the main crops are cereals with some oilseed/proteinaceous crops. As for type E, it is found in two small areas in Vendée and Centre, which are not alike. Type $\mathrm{F}$ and $\mathrm{H}$ are found in more diverse circumstances.

As for blackleg pressure and risk, the two regions studied are quite different: Vendée has a low blackleg pressure whereas Centre has a high blackleg pressure. Types A, B, and F are only found in the Centre of France where there is a higher blackleg pressure. The five other types are found in both blackleg zones.

The production system seems to influence farm type (Table 5). This can be explained for types D and G by the specific associated practices, which restrict these types to cereal producers. Type $\mathrm{H}$ concerns organic farms, which may or may not produce their own seed, and one conventional farmer who produces his own rape seed and has many constraints. Only types $\mathrm{C}$ and $\mathrm{E}$ seem to be less specific.

Organic farms are all found in type $\mathrm{H}$, except for the farm mixing conventional and organic cropping, whereas conventional cereal producers are found in different types. This is consistent with the definition of type $\mathrm{H}$ as identified by the classification tree, which is that the objective of type $\mathrm{H}$ is sustainability of the system, long crop rotation and few chemical inputs. One conventional oilseed rape producer also fits with this type.

We compared our results to the French statistical data available about farms' technical and economic features in both regions. According to the RICA of 2007 (Réseau d'Information Comptable Agricole, Agricultural Accounting Information Network) of the French Agricultural Statistics Service, in the Centre region $51 \%$ of the farms have a main income from crop farming, $12 \%$ from stock farming, and 13\% from both stock and crops. In the Pays de la Loire region (of which Vendée is a part), $11 \%$ of the farms have a main income from crop farming, $42 \%$ from stock farming, and $9 \%$ from both stock and crops. Our sample does not reflect these proportions. However, we did

Table 4 Geographical dispersion of the farm types

Types found in the survey

\begin{tabular}{lllllllll}
\hline Agricultural regions surveyed & A & B & C & D & E & F & G & H \\
Centre & 3 & 2 & 1 & 2 & 2 & 4 & 5 & 4 \\
Vendée & & & 3 & 2 & 3 & & 1 & 1 \\
\hline
\end{tabular}

not try to be representative of the features present in both regions but we tried to examine the diversity of features in these regions as is usually done to typify farms (Iraizoz et al. 2007) and our sample does reflect the wide diversity of systems present in both regions.

\subsection{Risk levels of the farm types}

The usual indicators of risk level for sustainability of varietal resistance to blackleg are return time for oilseed rape and varietal diversity. Figure 2 shows that these two criteria do indeed discriminate farm types according to their risk level but that these two criteria are not sufficient since some farm types span two classes for one or both of these criteria, like type C. Furthermore B and G types, which do not have the same risk level, overlap in the figure. This can be explained by the fact that $G$ type farms are more technical and in them, risk is also managed using techniques like crop residue management whereas B type farms tend to simplify cropping techniques. There are thus other factors which influence risk level. Our typology takes into account more criteria and better discriminates risk levels on the farm. Three groups in terms of erosion of varietal resistance to blackleg can be identified in Fig. 2:

- Those with a low level of risk (C, D, and H): type D has a very low level of risk since it combines a field pattern management and management practices to limit the adaptive response of blackleg. $\mathrm{C}$ and $\mathrm{H}$ types reduce the risk by lengthening the return time but their varietal diversity is less and their risk level is higher.

- Those with a mean level of risk (B, F, and G): G type farms have a mean level of risk because their return time for oilseed rape is short: they use a limited number of varieties and have changing management practices to adapt the crop to the environmental constraints rather than to pathogen constraints. $\mathrm{F}$ type farms are similar to these but their return time is even shorter. Type B includes only farmers investing little time in oilseed rape and using no mitigating practices.

- Those with a high level of risk (A and E): types A and E show low levels of varietal diversity and short return times, the same variety returning to a given field quite soon, which maximises the adaptive response of the pathogen.

Another result of our study is the capacity of each type of farm to adapt its management practices to increase sustainability of varietal resistance in the case of blackleg resurgence. Some types, such as B, could adapt, with changes in management being made if oilseed rape became more profitable. In type $\mathrm{C}$ farms, there is a low workload 
Table 5 Correspondence between farm type and production system. The same farm can be found both in the category 'on-farm produced seeds' and in another
Types found in the survey

Regions where present

\begin{tabular}{|c|c|c|c|c|c|c|c|c|c|}
\hline Production system & A & $\mathrm{B}$ & $\mathrm{C}$ & $\mathrm{D}$ & $\mathrm{E}$ & $\mathrm{F}$ & G & $\mathrm{H}$ & \\
\hline Organic farming & & & & & & & & 4 & Centre \\
\hline Mixed organic/conventional farming & & & 1 & & & & & & Centre \\
\hline Farmers using on-farm produced seeds & & & 1 & & & & 1 & 2 & Centre \\
\hline Legumes producing farmers & 1 & & & & 1 & & & & Centre, Vendée \\
\hline Oilseed rape seed producing farmers & & & 2 & & & & & & Vendée \\
\hline Crop and cattle producers & & 3 & 3 & & 1 & 1 & & & Centre, Vendée \\
\hline Conventional cereal producers & 2 & 1 & & 2 & 2 & 3 & 6 & 1 & Centre, Vendée \\
\hline
\end{tabular}

for oilseed rape and there is some flexibility left. Type $\mathrm{H}$ farms also show little interest in oilseed rape diseases but farmers are well-informed and innovative and if blackleg became important in their region, they could adapt their management practices since there is flexibility. Type D is also a flexible system but due to a high workload, management of oilseed rape cannot easily be changed.

As for the four other types (A, E, F, and G), changing oilseed rape management would not be easy. In the case of A farms, other activities are more important and there is little scope to change oilseed rape cropping. E type farms have high organisational constraints and $G$ type farms have high field pattern constraints, which leave them little room to adapt oilseed rape management. As for $F$ type farms, they have are well-informed and innovative but their farming systems are already optimised and they are not ready to adapt their management practices.
Based on our results, we can deduce that both return time and varietal diversity have a big influence on resistance breakdown, as has been shown by Rouxel et al. (2003). However, these two factors do not completely discriminate farm types according to their risk level. Other criteria either are able to compensate for (like crop residue management), or can increase, resistance breakdown risk (like simplified cropping techniques).

The geographical area affects the adoption of practices, not only through the blackleg risk (in areas with high blackleg pressure, farmers use less risky practices) but also through advisory areas. In the Bourges region, we have found more blackleg-conscious farmers than in Vendée and Beauce. This can be explained by the presence of advisors from CETIOM in this zone and a high level of information on blackleg's effect on yield and management practices in this zone. As noted by Maton et al. (2005), some uniformity of behaviour is found among farmers who have been
Fig. 2 Farm types and their associated risk level according to the varietal diversity of rapeseed found on the farms and the return times in the cropping system

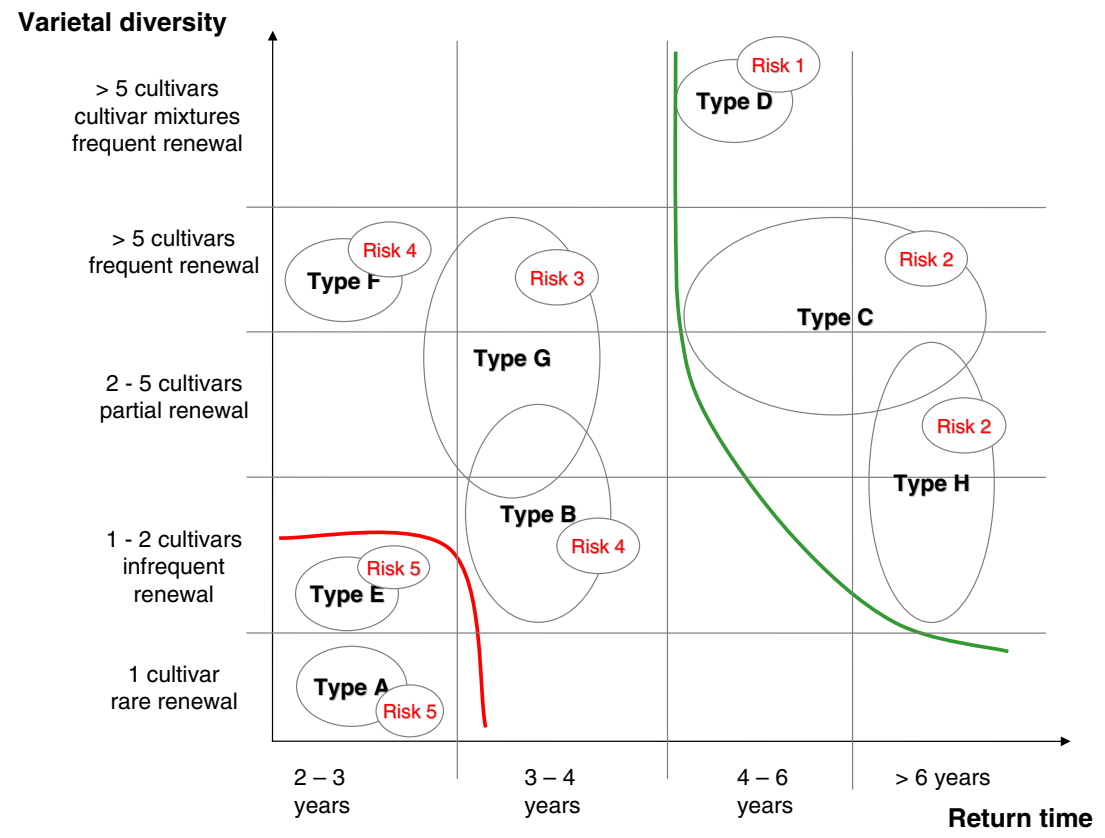


advised by the same advisors and share a part of their network.

\subsubsection{Flexibility within types}

Our typology also identified types, which could adopt recommended practices to diminish the risk level and those which couldn't.

We have found five farm types (A, B, E, F, and G) which do not use oilseed rape management practices that increase varietal resistance sustainability. All these risky types have nearly no flexibility and high constraints. Only one type, $\mathrm{B}$, has enough flexibility to adapt oilseed rape management practices but farmers in this type would be interested in change only if this crop became more profitable. This explains why, even though CETIOM, which advises farmers, tries to change oilseed rape management on farms, few farmers in these five types adopt its advice. Other studies have shown the importance of a participatory approach to introduce changes (McCown 2002; Woodward et al. 2008). Our study did not include farmer participation but it should help advisors discuss current practices and possible changes with farmers according to their farm type.

What is more surprising is that less risky farm types have more flexibility and could improve their oilseed rape management practices if needed. Type $\mathrm{C}$ farms have a relatively workload but even types $\mathrm{D}$ and $\mathrm{H}$ with a higher workload regroup farmers who could adapt their practices if necessary.

Fig. 3 Farm types can be distinguished by their investment in rape and the complexity of their system. Changes from one type to another are possible but sometimes difficult

\subsubsection{Getting more flexibility}

We also looked at the connections between types to analyse how the farms could change type slightly in order to diminish the risk level of their management system when they have no flexibility left within a type.

Looking at the characteristics of the farms in each type, we found that the eight types obtained can be segregated along two axes-farming system complexity and investment in work and resources for oilseed rape crops (Fig. 3) - to describe the types found. Common or similar elements join these types. For example, types B and C are similar but in the former, oilseed rape is really secondary whereas in the latter it is integrated into the farming system, involving different management practices and greater investment. Individual farms surveyed are in fact positioned in the spaces between these farms and can be related to a main type and a secondary one.

Thus a type E farm, which has a high risk of resistance breakdown but no flexibility would need to change its system to that of a type $\mathrm{G}$ to diminish this risk. This change of system would be possible only if the objectives attributed by the farmer to the rapeseed was higher and more time was devoted to this crop. As for the type A and $\mathrm{B}$, they would need to change to type $\mathrm{C}$ by limiting their use of simplified cropping techniques. Type $\mathrm{F}$ on the other hand would need to reduce the productivity objectives assigned to oilseed rape, which render this system risky in relation to blackleg resistance breakdown. Type $G$ is the closest type to $\mathrm{F}$ that is less risky.

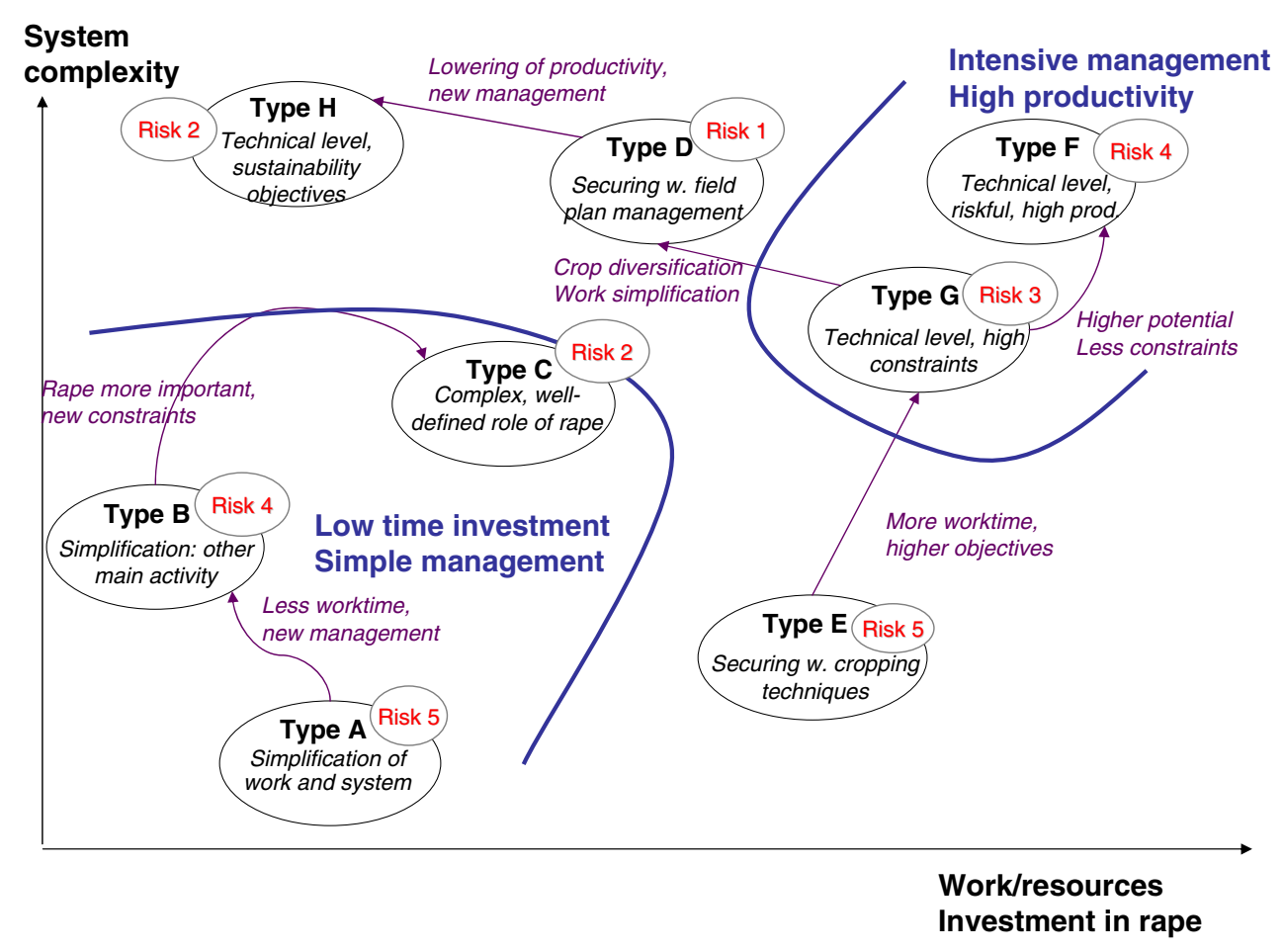

INAA פ Springer 


\section{Conclusion}

In this study, cropping system types were constructed as a combination of resources, techniques, and objectives; the relation with which was measured for the surveyed farms. Their constraints and management flexibility were also studied in order to identify risky types and possible improvements for each type.

This study is based on an adaptation to the oilseed rape crop of a methodology developed for sheep farms. It distinguishes farms based on their strategies without rigid limits. It could as well be used on other crop issues, like other pathogen-crop relations. It was slightly modified to adapt it to crop farming. The sampling method was directive and pre-selected the farm structures surveyed to study them in their maximum diversity. The semi-directive interviews were also re-centred on oilseed rape cropping, which was sometimes difficult for farms where oilseed rape is only a minor crop. However, open questions at the end of the interviews enabled us to learn about the determinants of the cropping systems and the constraints found on the farm. The data synthesis method seemed to be suited to crop farming as well as stock farming. However, the use of a dendrogram entails some information loss. Another difficult phase was the conversion of qualitative data into quantitative data because of its subjectivity. This was one of the reasons for introducing expert advice in this phase to limit the bias. The description of the system was thus more complex in crop farming, particularly in view of this pathosystem study since we had to combine practices at different levels, even though practices were individually simpler.

We found out that risky types are not always found in areas without blackleg and that several types of constraint explain the presence of risky types in regions with a high blackleg pressure.

Our results are now used by agricultural advisors of CETIOM to help them adapt their advice to farm types.

Acknowledgements The authors thank C. Auguste for his help in conducting farmers' interview and for his expert knowledge of farming. The authors are also grateful to X. Pinochet, B. Rémy and J-N. Aubertot for expert advice. This work was carried out with the financial support of the ANR (Agence Nationale pour la Recherche, French National Research Agency) under the Programme Agriculture et Développement Durable, project ANR-05-PADD-05, CEDRE.

\section{References}

Aubertot JN, Brun H, Lemarié S, Messean A, Pinochet X, Renard M, Rouxel T (2004) Durable management of oilseed rape resistances to blackleg stem canker. In: Les entretiens du Pradel, agronomes et innovations, Sept. 2004, France
Aubertot JN, West JS, Bousset-Vaslin L, Salam MU, Barbetti MJ, Diggle AJ (2006) Improved resistance management for durable disease control: a case study of blackleg stem canker of oilseed rape (Brassica napus). Eur J Plant Pathol 114:91-106. doi:10.1007/s10658-005-3628-z

Bradshaw JM, Ford KM, Adams-Webber JR, Boose JH (1993) Beyond the repertory grid: new approaches to constructivist knowledge acquisition tool development. Int $\mathrm{J}$ Intell Syst $8: 287-333$

Carberry PS, Hochman Z, McCown RL, Dalgliesh NP, Foale MA, Poulton PL, Hargreaves JNG, Hargreaves DMG, Cawthray Z, Hillcoat N, Robertson MJ (2002) The FARMSCAPE approach to decision support: farmers', advisers', researchers' monitoring, simulation, communication and performance evaluation. Agr Syst 74:141-177. doi:10.1016/S0308-521X(02)00025-2

Coléno FC, Duru M, Theau JP (2005) A method to analyse decisionmaking processes for land use management in livestock farming. Int J Agric Sustain 3(1):69-78

Cros MJ, Duru M, Garcia F, Martin-Clouaire R (2003) A biophysical dairy farm model to evaluation rotational grazing. Agronomie 23:105-122. doi:10.1051/agro:2002071

Dedieu B, Ingrand S (2010) Incertitude et adaptation: cadres théoriques et application à l'analyse de la dynamique des systèmes d'élevage. INRA Productions animales 23(1):81-90

Fitt BDL, Brun H, Barbetti MJ, Rimmer SR (2006) World-wide importance of blackleg stem canker (Leptospheria maculans and L. biglobosa) on oilseed rape (Brassica napus). Eur J Plant Pathol 114:3-15. doi:10.1007/s10658-005-2233-5

Girard N, Bellon S, Hubert B, Lardon S (2001) Categorising combinations of farmers' land use practices: an approach based on examples of sheep farms in the south of France. Agronomie 21:435-459. doi:10.1051/agro:2001136

Girard N, Duru M, Hazard M, Magda D (2008) Categorising farming practices to design sustainable land-use management in mountain areas. Agron Sustain Dev 28:333-343. doi:10.1051/ agro:2007046

Iraizoz B, Gorton M, Davidova S (2007) Segmenting farms for analysing agricultural trajectories: a case study of the Navarra region in Spain. Agr Syst 93:143-169. doi:10.1016/j.agsy.2006.05.002

Khangura RK, Barbetti MJ (2001) Prevalence of blackleg (Leptospheria maculans) on canola (Brassica napus) in Western Australia. Aust J Exp Agr 41:71-80. doi:10.1071/EA00068

Köbrich C, Rehman T, Khan M (2003) Typification of farming systems for constructing representative farm models: two illustrations of the application of multi-variate analyses in Chile and Pakistan. Agr Syst 76:141-157. doi:10.1016/S0308-521X (02)00013-6

Landais E (1998) Modelling farm diversity. New approaches to typology building in France. Agr Syst 58:505-527. doi:10.1016/S0308-521X (98)00065-1

Marcroft SJ, Sprague SJ, Salisbury PA, Howlett BJ (2004) Potential for using host resistance to reduce production of pseudothecia and ascospores of Leptosphaeria maculans, the blackleg pathogen of Brassica napus. Plant Pathol 53:468-474. doi:10.1111/ j.1365-3059.2004.01050.x

Maton L, Leenhardt D, Goulard M, Bergez J-E (2005) Assessing the irrigation strategies over a wide geographical area from structural data about farming systems. Agr Syst 86:293-311. doi:10.1016/j. agsy.2004.09.010

McCown RL (2002) Changing systems for supporting farmers' decisions: problems, paradigms and prospects. Agr Syst 74:179-220. doi:10.1016/S0308-521X(02)00026-4

Mestries E (2005) Les stratégies durables de la gestion du mildiou. Oléoscope 83:25-28

Miles MN, Huberman AM (1994) Qualitative data analysis, an expended sourcebook, 2nd edn. Sage, Thousand Oaks 
Naseri B (2006) Epidemiology of blackleg disease of canola, caused by Leptospheria maculans. PhD, University of Adelaide (Australia)

Rosch E (1978) Principle of categorization. In: Lloyd BB, Rosch E (eds) Cognition and categorization. Lawrence Erlbaum, Hillsdale, NJ, pp 27-48

Rouxel T, Penaud A, Pinochet X, Brun H, Gout L, Delourme R, Schmit J, Balesdent MH (2003) A 10-year survey of populations of Leptospheria maculans in France indicates a rapid adaptation towards the Rlm 1 resistance gene of oilseed rape. Eur J Plant Pathol 109:871-881. doi:10.1023/A:1026189225466

Schneider O, Roger-Estrade J, Aubertot JN, Doré T (2006) Effect of seeders and tillage equipment on vertical distribution of oilseed rape stubble. Soil Till Res 85:115-122. doi:10.1016/j.still.2004.12.007

Sivasithamparam K, Barbetti MJ, Li H (2005) Recurring challenges from a necrotrophic fungal plant pathogen: a case study with
Leptosphaeria maculans (causal agent of blackleg disease in Brassicas) in Western Australia. Ann Bot Lond 96:363-377. doi:10.1093/aob/mci194

Sprague SJ, Balesdent MH, Brun H, Hayden HL, Marcroft SJ, Pinochet X, Rouxel T, Howlett BJ (2006) Major gene resistance in Brassica napus (oilseed rape) is overcome by changes in virulence of populations of Leptospheria maculans in France and in Australia. Eur J Plant Pathol 114:33-40. doi:10.1007/s10658005-3683-5

West JS, Kharbanda PD, Barbetti MJ, Fitt BDL (2001) Epidemiology and management of Leptospheria maculans (blackleg stem canker) on oilseed rape in Australia, Canada and Europe. Plant Pathol 50:10-27. doi:10.1046/j.1365-3059.2001.00546.x

Woodward SJR, Romera AJ, Beskow WB, Lovatt SJ (2008) Better simulation modelling to support farming systems innovation: review and synthesis. New Zeal J Agr Res 51(3):235-252 